\title{
CONSTANTIN DOBROGEANU-GHEREA, AS DIFICULDADES DA TRADUÇÃO ${ }^{1}$
}

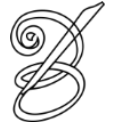 \\ Traduzido por: \\ Ana Alethea de Melo Cesar OSÓRIO* \\ Universidade de Brasília \\ Brasília, Distrito Federal, Brasil \\ Ruxandra INDREȘ** \\ Universidade do Oeste de Timisoara \\ Timisoara, Timis, Romênia
}

RECEBIDO EM: 10 de novembro de 2019

ACEITO EM: 30 de novembro de 2019

PUBLICADO EM: abril 2020

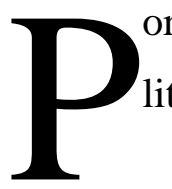

or razões alheias à minha vontade, interrompi a série de artigos sobre traduções literárias; retomo-a, portanto, neste momento.

No último artigo vimos como a transformação de ideias, sentimentos e relações sociais causou uma revolução correspondente na linguagem literária após a introdução da civilização ocidental em nosso país, e como esta revolução ainda não terminou.

Vejamos agora qual teria sido o critério, a norma, para as mudanças que deveriam ter ocorrido no interior da língua romena. É claro que novas ideias e relações sociais muitas vezes exigiam novas palavras, a extensão do significado de algumas palavras existentes, ou a combinação de palavras, mas qual seria a norma e o critério para todas essas mudanças?

A norma é a própria linguagem literária que se formou ao longo de tantos séculos. As mudanças que supostamente ocorrem na língua são aquelas que a linguagem literária já formada poderia admitir. Os novos escritores tiveram, portanto, que primeiro estudar a fundo a linguagem literária de seus pais, dar a ela toda a flexibilidade e expressividade possíveis, introduzindo apenas aqueles elementos que eram absolutamente necessários e capazes de se adaptar e viver no novo meio - o organismo da língua romena.

Será que nossos escritores fizeram isso? Sabemos muito bem que não; mas isso não nos interessa agora. É uma pergunta completamente diferente que requer uma resposta. Se é óbvio que nem todo neologismo, nova construção ou nova combinação de palavras pode se adaptar e 
existir numa língua, e que só quem tem uma certa afinidade com essa língua é capaz de fazer isso, então surge uma pergunta: como e por que meios podemos descobrir esses neologismos, esses novos elementos, que têm afinidade com a linguagem literária em questão e podem adaptar-se a ela e nela permanecer? Infelizmente, não há nada que possamos fazer, a ciência da linguagem - a filologia - não nos ajuda muito nesse respeito.

A filologia estuda uma linguagem que já foi formada, não a cria.

Só um sentido artístico especial poderia encontrar esses elementos. (Descobrir estes elementos só é possível com um sentido artístico especial.) Só o artista dotado desse sentido especial pode adivinhar a palavra real, a que vai perdurar. Novas palavras e combinações de palavras passam miraculosamente pela peneira do temperamento e do significado artístico e apenas permanecem nela aquelas que resistirão na linguagem literária.

Se essas palavras forem precisas - e perfeitamente precisas -, então fica claro por que os artistas e não os filólogos manejam esse instrumento - a linguagem literária -, porque eles a reformam.

Outras qualidades intelectuais caracterizam um grande filólogo e um grande filólogo

154 poderia ser completamente desprovido do sentido artístico necessário para reformar a linguagem literária. Um grande artista não reforma a linguagem pelo simples fato de usar este ou aquele novo elemento, mas adivinhando o novo elemento necessário.

Assim, de dois termos estrangeiros, cada um mais belo que o outro, bela ("bela") e etern (“eterno") (que têm como correspondentes em romeno: frumoasă e več̆nic), somente a palavra etern permaneceu na linguagem literária. Mas essa palavra não permaneceu porque Eminescu a empregou num verso brilhante; Eminescu empregou-a porque ela deveria permanecer, porque, por simples intuição artística, Eminescu sentiu que era uma palavra que deveria existir na língua romena.

Por causa do que acabamos de dizer neste artigo e em artigos anteriores, podemos ver claramente as grandes dificuldades que os tradutores de obras literárias estrangeiras encontram. A opinião geral de que basta dominar a língua que se traduz [língua fonte] e a língua para a qual se traduz [língua-alvo] é totalmente errada. Em uma importante obra de arte há uma grande riqueza de ideias originais, uma multidão de belas imagens, uma análise psíquica fina, uma construção erudita da obra completa, e tudo isso deve ser perfeitamente compreendido e traduzido pelo tradutor, mantendo-se, na medida do possível, a mesma potência que a do original. 
O tradutor deve mergulhar na atmosfera do trabalho artístico, por assim dizer. Por exemplo, Crime e Castigo, obra genial de Dostoievski.

Há nela, além de uma análise psicológica surpreendente, cenas dolorosas, a vida desesperada dos personagens, uma atmosfera onde tudo acontece e que reforça a impressão e a emoção sentidas ao se ler o romance. Há um misticismo religioso, o temperamento doente do grande artista, há a vida terrível na Rússia, que dá a toda a obra um tom tão sombrio que não é negado por nenhuma palavra ao longo dos dois grandes volumes.

Traduzir exatamente, página por página, sem imprimir esse tom geral do romance significa traduzir mal. Para que um tradutor seja capaz de reconstituir pela mesma força que o original a análise psíquica dos personagens, as finas nuances dos sentimentos, a beleza das imagens, a força das ideias, e de reproduzir em nós toda a atmosfera da obra de arte, seu tom geral, seu estilo particular, ele deve estar imerso na obra de arte, viver a mesma vida, com todas as emoções que o artista experimentou ao criar sua obra - para tudo isso o tradutor deve também ter um temperamento artístico.

No nosso país, todas essas dificuldades são duplicadas pela dificuldade da linguagem literária não fixa. Para expressar toda a complexidade e riqueza de ideias, imagens e sentimentos da obra estrangeira, o tradutor muitas vezes não encontra palavras e expressões na nossa pobre língua literária romena e será, então, obrigado a introduzir novas palavras, para dar um significado mais amplo a palavras antigas, etc., mas, para fazer tudo isso, já mencionamos a necessidade de um sentido artístico especial. Consequentemente, o tradutor deve ser ele mesmo um artista também. Evidentemente que uma criação original é infinitamente mais difícil do que uma tradução, mas traduzir da forma como falamos significa criar. Uma grande obra de arte traduzida tão perfeitamente terá uma influência muito grande na nossa literatura e terá uma influência decisiva na formação da linguagem literária.

É por isso que cada um de nossos escritores importantes deveria ser considerado para realizar a tradução de ao menos uma grande obra estrangeira como um dever moral para com a literatura do país.

Assim, teríamos testemunhado o nascimento de uma literatura traduzida rica, e traduzida da maneira que acabamos de comentar. Agora, só nos resta ver o que se deve traduzir. Discutiremos isso no artigo seguinte. 
${ }^{1}$ Tradução de:
Constantin Dobrogeanu-Gherea, “Greutățile traducerei” In: Lumea Nouă, 1894, No 25, p. 1. BCU Iași.

* Ana Alethea de Melo Cesar OSÓRIO - Bacharel em Letras - Tradução/Inglês (2011) pela Universidade de Brasília. Especialista em Revisão de Textos (2015) pelo Centro Universitário de Brasília. Mestranda em Estudos da Tradução na Universidade de Brasília. Revisora de textos na Editora Universidade de Brasília. Universidade de Brasília, Instituto de Letras, Programa de Pós-Graduação em Estudos da Tradução. Brasília, Distrito Federal, Brasil.

Currículo acadêmico: http://lattes.cnpq.br/5685363692393264

ORCID: https://orcid.org/0000-0002-2101-9566

E-mail: anaalethea@gmail.com

** Ruxandra INDRES - Doutoranda em Tradutologia pela Universidade do Oeste de Timisoara, Romênia. Participou do projeto de tradução de Les traducteurs dans l'histoire (EUV, 2008). Professora adjunta, tradutora e intérprete. Universidade do Oeste de Timisoara, Timișoara, Timis, Romênia.

ORCID: https://orcid.org/0000-0002-7411-4540

E-mail: ruxije_18@yahoo.com 